\title{
Disgusting or delicious? Predatory behavior of the hylid frog Phyllodytes luteolus on sympatric ants
}

\author{
Mirco Solé1 \& Daniel Loebmann²
}

\begin{abstract}
1. Universidade Estadual de Santa Cruz, Departamento de Ciências Biológicas, Rod. Jorge Amado, Km 16, 45662-900, Ilhéus, BA, Brasil. (msole@uesc.br)
2. Universidade Federal do Rio Grande, Instituto de Ciências Biológicas, Laboratório de Vertebrados. Av. Itália km 8, 96203-900, Rio Grande, RS, Brasil. (contato@danielloebmann.com)
\end{abstract}

Received 2 July 2016

Accepted 26 May 2017

DOI: 10.1590/1678-4766e2017030

\begin{abstract}
The phytotelm-dwelling frogs from the genus Phyllodytes Wagler, 1830 have been characterized as specialist frogs regarding their diet strategy which is mainly composed by colonial insects. Herein, we used two species of ants (Camponotus sp. and Gnamptogenys sp.) with distinct defensive mechanisms to test the predatory behavior of Phyllodytes luteolus Wied, 1824. The experiment was conducted with frogs inhabiting a patch of 20 bromeliads (Aechmea $\mathbf{c f}$. blanchetiana). Ants were offered randomly to the frogs until we obtained ten observations of predation of each ant species. We observed and recorded the time that $P$. luteolus needed to keep each ant species inside its mouth before it could ingest it. Predatory behavior was highly distinct. While Camponotus were caught and swallowed within six seconds and without apparent discomfort, individuals of $P$. luteolus had more difficulty in swallowing Gnamptogenys individuals, the time of manipulation ranging from 57 to 177 seconds. The mean values of time of predation observed in each treatment was highly significant $(\mathrm{p}<0.001)$. We conclude that differences found in the time of manipulation are highly correlated with defense mechanisms of each species of ants.
\end{abstract}

KEYWORDS. Behavior, Camponotus, Gnamptogenys, bromeliads, predation.

RESUMO. Nojento ou delicioso? Comportamento predatório da perereca Phyllodytes luteolus sobre formigas simpátricas. As pererecas que habitam fitotelmatas do gênero Phyllodytes Wagler, 1830 têm sido caracterizadas como especialistas em relação à sua estratégia de dieta, que é composta principalmente por insetos coloniais. Neste trabalho, usamos duas espécies de formigas (Camponotus sp. e Gnamptogenys sp.) com mecanismos de defesa diferentes para testar o comportamento predatório de Phyllodytes luteolus Wied, 1824. O experimento foi conduzido com pererecas que habitavam uma mancha de 20 bromélias (Aechmea cf. blanchetiana). As formigas foram oferecidas aleatoriamente para as pererecas até que obtivemos dez observações de predação para cada espécie de formiga. Observamos e registramos o tempo que $P$. luteolus precisou manter cada espécie de formiga dentro da boca antes da mesma poder ser ingerida. O comportamento de predação foi altamente distinto. Enquanto Camponotus foram capturadas e engolidas dentro de seis segundos e sem desconforto aparente, indivíduos de P. luteolus tiveram maiores dificuldades em engolir indivíduos de Gnamptogenys, com tempo de manipulação variando de 57 a 177 segundos. Os valores médios do tempo de predação em cada tratamento foram altamente significativos (p<0.001). Concluímos que as diferenças encontradas no tempo de manipulação estão altamente correlacionadas com os mecanismos de defesa de cada espécie de formiga.

PALAVRAS-CHAVE. Comportamento, Camponotus, Gnamptogenys, bromélias, predação.

The Yellow Heart-tongued Frog Phyllodytes luteolus Wied, 1824 is distributed along the Atlantic Forest of Brazil, from the state of Paraíba to the north of the state of Rio de Janeiro (VRCIBRADIC et al., 2006; HADDAD et al., 2013). Individuals are commonly found inside bromeliads thriving in open areas, in axils usually containing at least $100 \mathrm{ml}$ of water (TEIXEIRA et al., 1997). Reproduction also takes place in bromeliad axils where each female may lay up to three eggs and where tadpoles develop feeding on debris (Регхото, 1995; GiaretTA, 1996). Although its diet is diversified, $P$. luteolus has been considered a specialist regarding its foraging strategy once its diet is mainly composed by colonial insects (FERREIRA et al., 2012). Feeding on ants and termites seems to be the common share for several bromeligenous and bromelicolous frog species as e.g. Thoropa miliaris (Spix, 1824) and Scinax arduous Peixoto, 2002 (Pertel et al., 2010). However, MotTA-TAVAres et al. (2016) argued that it is not possible to assume diet strategy of species if no studies evaluate whether frogs select prey items or if they consume them according to prey availability inside bromeliads. Moreover, ants possess a very large arsenal of defense strategies involving chemical defenses as formic acid (FALÓtico et al., 2007), stinging (HADDAD JR \& LARSSON, 2015) and biting (PEETERs \& ITO, 2015). As amphibians from several species have been reported to sequester alkaloids from dietary arthropods as ants and mites (HANTAK et al., 2013) they should be able to deal with these defense strategies to overwhelm their prey. In order to aid to elucidate this dilemma 
we set up an experiment offering two sympatric species of ants with distinct defense mechanisms (chemical and stinging) to specimen of $P$. luteolus inside bromeliad axils. We wanted to find out if there would be differences on the time of prey processing in relation to the defense mechanism of the ant. As no previous behavioral information on how bromeliad frogs deal with ants exist we hypothesize that both species possess attributes that may delay or accelerate their ingestion. On one hand frogs may try to swallow ants with a sting rapidly, thus neutralizing the risk of being stung. On the other hand they may delay the ingestion in order to avoid being stung while the ant is still alive inside their stomach.

\section{MATERIALS AND METHODS}

To carry out the experiment we used individuals of Phyllodytes luteolus as predators and two species of ants of similar size — Camponotus sp. and Gnamptogenys sp. as target species. Both ants occur in syntopy with the frogs and were chosen based on previous ad libitum observations performed by MS which revealed that $P$. luteolus were able to prey on them. Individuals of $P$. luteolus used in the experiment inhabited a patch of 20 bromeliads (Aechmea cf. blanchetiana), which were cultivated by MS since 2010 in the municipality of Ilhéus, state of Bahia, Brazil (1454'44.3”S, $\left.39^{\circ} 01^{\prime} 27.8^{\prime \prime} \mathrm{W}\right)$. This population of $P$. luteolus comprised around 80 individuals. The experiment was conducted on October $1^{\text {st }} 2014$ between 22:00h and 24:00h until we obtained ten observations of predation of each ant species. Ants, which had been previously collected in activity during the same night at the study site, were gently placed manually inside bromeliad axils containing a randomly chosen frog. For each ant offered we observed and recorded the manipulation time in the mouth that $P$. luteolus needed to ingest each one. To compare the time of predation between each treatment (prey models) we performed a t-test $(\mathrm{p}<0.05)$.

\section{RESULTS}

Predatory behavior was highly distinct between both ant species. While Camponotus sp. were caught and swallowed in up to six seconds (mean $=2.4 \pm 2.27$; $\mathrm{n}=$ 10) and without apparent distress, those individuals of Phyllodytes luteolus that tried to feed on Gnamptogenys sp. showed more difficulty in swallowing them. Frogs manipulated individuals of Gnamptogenys sp. with their mouth, keeping the abdomen of the prey outside for 57 to 177 seconds $($ mean $=108.3 \pm 48.52 ; \mathrm{n}=10)$, in order to avoid injuries due to the ant's sting (Fig. 1). The mean values observed among the time of predation in each treatment were highly significant $(\mathrm{p}<0.001)$. We also noted that for Gnamptogenys sp., amphibians opened their mouth several times until they finally managed to swallow their prey.

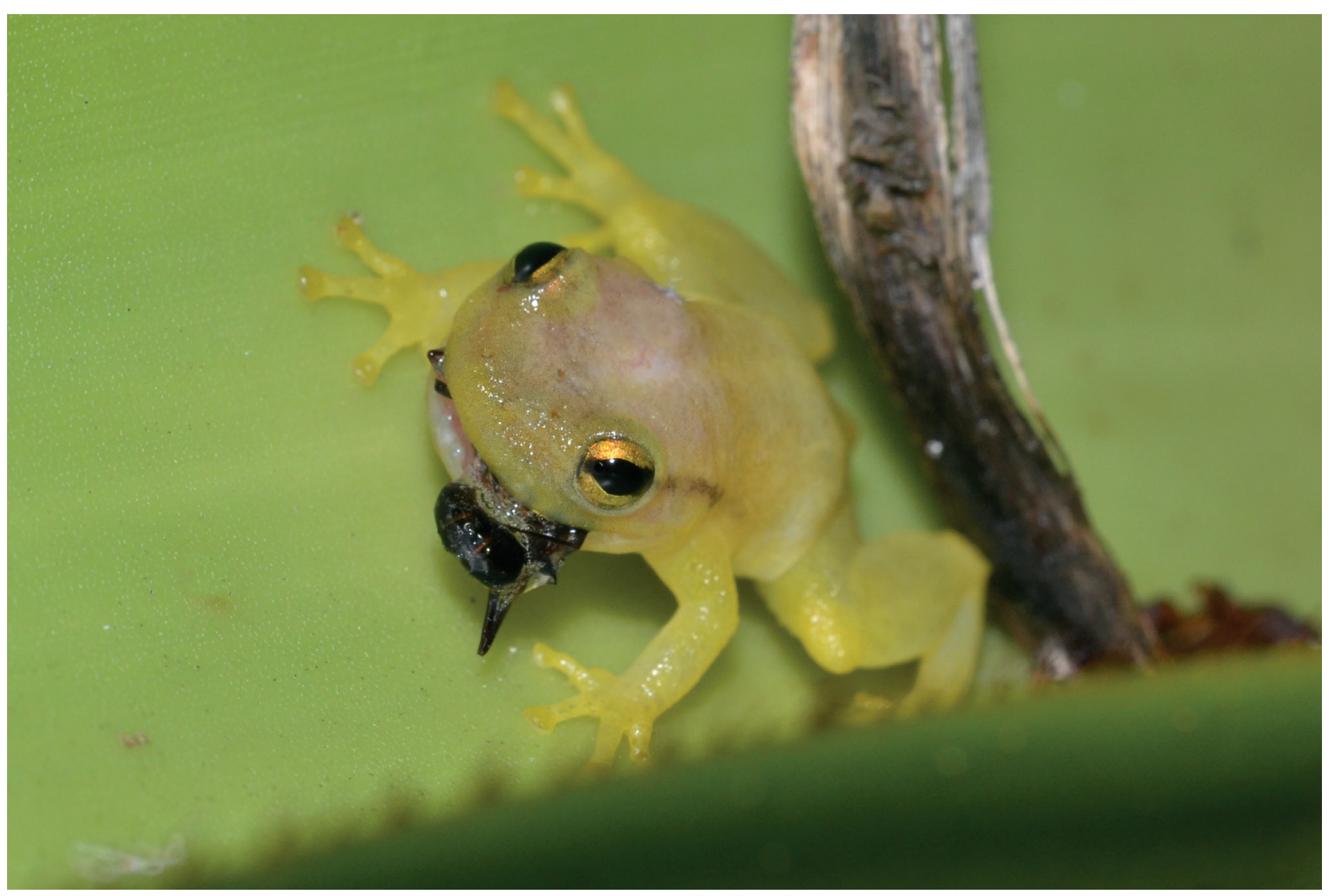

Fig. 1. Phyllodytes luteolus Wied, 1824 manipulating its prey, an ant of the genus Gnamptogenys. Note that the frog has kept the abdominal region of the ant outside of the mouth in order to prevent injuries caused by its sting. 


\section{DISCUSSION}

Defensive tactics in prey forced predators to coevolve simultaneously generating a predator-prey arms race (BRODIE \& BRODIE, 1999a,b; GeFFENEY et al., 2002). Results provided by our experiment demonstrated that Camponotus sp. and Gnamptogenys sp. can be consumed by Phyllodytes luteolus, but with distinct behaviors for each ant species. As both ant species are similar in size this result can be explained due to the distinct defense mechanisms against predators of those ant species. While Camponotus sp. can use its well-developed jaws as a defense mechanism Gnamptogenys sp. injects formic acid through its stinger located at the final portion of its abdomen. Although P. luteolus showed ability to withstand the discomfort caused by the defense mechanisms of both ants, the pain caused by Gnamptogenys stinging seemed to be much more uncomfortable than the bites inflicted by Camponotus sp. (authors pers. obs.). We conclude that individuals of $P$. luteolus are adapted to eat both targeted species of ants. Future studies using simultaneously both ant species to test prey preferences would be useful to determine the capacity of prey selection in $P$. luteolus.

Acknowledgments. We are grateful to Michelle Pazmino for comments and suggestions on the draft version of this manuscript.

\section{REFERENCES}

Brodie, E. D. III \& BRodiE, E. D. JR. 1999a. Costs of exploiting poisonous prey: evolutionary trade-offs in a predatory-prey arms race. Evolution 53(2):626-631.

Brodie, E. D. III \& Brodie, E. D. JR. 1999b. Predator-prey arms races. Asymmetrical selection on predators and prey may be reduced when prey are dangerous. BioScience 49(7):557-568.

Falótico, T.; Labruna, M. B.; Verderane, M. P.; De Resende, B. D.; Izar, P. \& OtToni, E. B. 2007. Repellent efficacy of formic acid and the abdominal secretion of Carpenter Ants (Hymenoptera: Formicidae) against Amblyomma ticks (Acari: Ixodidae). Journal of Medical Entomology 44(4):718-721.

Ferreira, R. B.; Schineider, J. A. P. \& Teixeira, R. L. 2012. Diet, Fecundity, and Use of Bromeliads by Phyllodytes luteolus (Anura: Hylidae) in Southeastern Brazil. Journal of Herpetology 46(1):19-24.

Geffeney, S.; Brodie, E. D. JR. \& Brodie, E. D. III. 2002. Mechanisms of adaptation in a predator-prey arms race: TTX-resistant sodium channels. Science 297(5585):1336-1339.

GiARETTA A. A. 1996. Reproductive specializations of the bromeliad hylid frog Phyllodytes luteolus. Journal of Herpetology 30(1):96-97.

Haddad, C. F. B.; Toledo, L. F.; Prado, C. P. A.; Loebmann, D.; Gasparini, J. L.; Sazima, I. 2013. Guia dos Anfíbios da Mata Atlântica: Diversidade e Biologia. São Paulo, Anolisbooks. 544p.

HADDAD JR, V. \& LARSSON, C. E. 2015. Anaphylaxis caused by stings from the Solenopsis invicta, lava-pés ant or red imported fire ant. Anais Brasileiros de Dermatologia 90(3) (Suppl 1):22-25.

Hantak, M. M.; Grant, T.; Reinsch, S.; McGinnity, D.; Loring, M.; TOYOOKA, N. \& SAPORITO, R.A. 2013. Dietary alkaloid sequestration in a poison frog: an experimental test of alkaloid uptake in Melanophryniscus stelzneri (Bufonidae). Journal of Chemical Ecology 39(11):1400-1406.

Motta-Tavares, T.; Maia-Carneiro, T.; Dantas, L. F.; Van Sluys, M.; Hatano, F. H.; Vrcibradic, D. \& Rocha, C. F. D. 2016. Ecology of the bromeligenous frog Phyllodytes luteolus (Anura, Hylidae) from three restinga remnants across Brazil's coast. Anais da Academia Brasileira de Ciências 88(1):93-104.

Peeters, C. \& Ito, F. 2015. Wingless and dwarf workers underlie the ecological success of ants (Hymenoptera: Formicidae). Myrmecological News 21:117-130.

Pеiхото, O. L. 1995. Associação de anuros a bromeliáceas na Mata atlântica. Revista da Universidade Rural. Série Ciências da Vida 17(2):75-83.

Pertel, W.; Teixeira, R. L. \& Ferreira, R. B. 2010. Comparison of diet and use of bromeliads between a bromelicolous and a bromeligenous anuran at an Inselberg in the southeastern of Brazil. Caldasia 32(1):149-159.

Teixeira, R. L.; Zamprogno, C.; Almeida, G. I. \& Schineider, J. A. P. 1997. Ecological topics of Phyllodytes luteolus (Amphibia: Hylidae) in a Sandy coastal plain of São Mateus, Espírito Santo state. Revista Brasileira de Biologia 57(4):647-654.

Vrcibradic, D.; Hatano, F. H.; Rocha, C. F. D. \& Van Sluys, M. 2006. Geographic distribution: Phyllodytes luteolus. Herpetological Review 37(4):489. 